\title{
Road Block in the Streets of Brussels
}

\author{
Hergé in Translation
}

\section{ELKE BREMS \\ University College Brussels (K.U. Leuven Association), Belgium}

\begin{abstract}
This paper examines the translations of Hergé's comic strip Quick \& Flupke during the period 1940-1990. When Quick \& Flupke was first published in a francophone Belgian newspaper in the 1930s, it portrayed the complex linguistic character of Brussels, where the adventures of the street boys are set. Hergé 's characters employed the type of linguistic code-switching between French and Dutch that was typical for the inhabitants of Brussels at the time. The original comic strip also contained cultural references to Brussels and Belgium. A comparative analysis of the first French version and the first Dutch translations of the comic, which appeared in Flemish newspapers in the 1940s, with the most recent Dutch and French translations from the 1990s reveals important changes in both the intralingual and interlingual translations. In particular, the analysis reveals how economic and cultural-political factors have led to the increased standardization of textual (and some pictorial) aspects of the comic strip which has made it less Belgian and more international. The paper demonstrates how different translations of the comic strip operate at the micro level as an indicator of the changes that have taken place in the linguistic and cultural identities of Belgians and Brusselers.
\end{abstract}

Keywords. Comic strip translation, Global/Local, Cultural identity, Multilingualism, Dialects, Hergé.

\begin{abstract}
In a way, Brussels is our Jerusalem. ... It is a symbol claimed by both ethnic groups as their sacred place. By the Flemish because it lies at the heart of their region and the man in the street has been speaking Flemish in Brussels for centuries. By the Walloons because Brussels has become a capital in French, which is why French is the language Brusselers know best nowadays. To let go of Brussels would be an unbearable humiliation for both sides. (my translation) ${ }^{1}$
\end{abstract}

\footnotetext{
1 "Brussel is een beetje ons Jeruzalem. ... Brussel is een symbool waarop onze beide etnieën heilige aanspraken menen te hebben. De Vlamingen omdat het in het hart van hun gewest ligt en de kleine man in Brussel eeuwenlang Vlaams heeft gesproken. De Walen omdat 
The Belgian scholar, Philippe van Parijs, wrote these words on 14 June 2011 in the Flemish newspaper De Standaard. His words are just one example out of many concerning what is known as the 'Brussels Question'. If what Reine Meylaerts writes is true, that in Belgium "matters of language and identity have proved ... complex, fluctuating and problematic" (Meylaerts 2007:297), then it is even more true for Brussels, its capital, where all Belgian matters culminate. Belgium is a bilingual country: ${ }^{2}$ Dutch is spoken in the North and French in the South. Brussels, which lies in the Dutch-speaking part of the country, is a bilingual city ${ }^{3}$ where French is the dominant language. French was dominant in Belgium until around World War II, and the Dutch-speaking Belgians - the Flemish $^{4}$ - have long waged a cultural war against this dominance. After World War II a series of (ongoing) political reforms gave increasingly more autonomy to both linguistic communities, resulting in a loosening of the ties between Belgium's French-speaking and Dutch-speaking communities and reducing the impact of Belgium at the bilingual and federal level. This article discusses how the translation of the comic strip Quick \& Flupke, created by Georges Remi (1907-1983; better known as Hergé), mirrors this complex social-linguistic context, the evolving relationship between these two linguistic groups and the changing identity of Brussels and of Belgium between the 1940s and the 1990s.

Hergé is best known for creating one of Belgium's most famous icons, Tintin, in the eponymous comic strip named after the imaginary son of the writer, who was 'born' in the youth supplement of the francophone newspaper Le Vingtième Siècle. The supplement was called Le Petit Vingtième; it was supervised from the time of its origin in 1928 by Hergé, who used it to try out new comic characters and develop his artistic talents. In 1929, he invented the character of a young reporter who travelled the world - the boy, named Tintin, soon became immensely popular with readers, and very lucrative for the newspaper.

Although Hergé and his work are considered part of national heritage by both French- and Dutch-speaking Belgians, Tintin has been used especially

Brussel in het Frans een hoofdstad is geworden en het bijgevolg vandaag de taal is die de Brusselaars het best kennen. Brussel loslaten zou voor beide kampen een ondraaglijke vernedering zijn" (Van Parijs 2011).

${ }^{2}$ Belgium also has a very small German language community which is not involved in the struggles over language.

${ }^{3}$ Although Brussels is often still considered a bilingual city, with both Dutch-speaking and French-speaking inhabitants, nowadays the social reality is that Brussels is a multilingual city where English plays a strong role, not least because of Brussels' position in Europe. However, in the historical case presented here, this is not a relevant factor.

${ }^{4}$ In the past, being Flemish meant you belonged to the Flemish people, it did not necessarily imply you were Dutch-speaking. Francophones could be considered Flemish, but those were often considered 'franskiljons', traitors of their Flemish roots (Meylaerts 2008 b). 
to enhance the cultural identity of francophone Belgians. In the edited book Tintin, Hergé et la Belgité (Soncini Fratta 1994), Tintin is associated with the term 'belgite', which refers to a cultural identity specifically linked to francophone Belgium. Matthew Screech, in his book Masters of the Ninth Art: Bandes Dessinées and Franco-Belgian Identity (2005:50), calls Tintin a "Franco-Belgian hero", emphasizing the bonds between Belgium and France. He remarkably concludes that,

Thanks to Hergé, the ninth art carved out a new Franco-Belgian identity: the French and the Belgians, divided and humiliated under occupation, needed to fashion a new identity in the post-war, postimperial world....Throughout the historical and political upheavals of the mid-20th century, Tintin resolutely stood his ground as a steadfast Franco-Belgian hero; Tintin was a bold righter of wrongs, who lived both in France and Belgium.

Although many books and articles have been written about Hergé and about Tintin, his most famous comic character, far less attention has been paid to his many other character creations, such as the boy scout, Totor, Jo, Suus and their monkey Jokko or, the focus of this article, the eponymously titled comic strip Quick \& Flupke.

\section{Two more sons of Hergé: Quick and Flupke}

The comic strip Quick \& Flupke was first published in Le Petit Vingtième on 23 January 1930. Every week, both boys lived an adventure that occupied two pages of Le Petit Vingtième. As a newspaper comic strip, Quick \& Flupke belongs to the genre of humorous comics, which are "usually self-conclusive, a series of variations on a restricted number of themes and situations ending up with a final gag" (Zanettin 2008:7).

Like Tintin, this comic strip soon became very popular and successful, and for the next five years Hergé wrote and illustrated the bulk of the strips. Up until 1935 the strip appeared very frequently in Le Petit Vingtième; after that, until 1940, it appeared only off and on. During the war, some new episodes appeared in Le Soir, which was then in German hands. ${ }^{5}$ Collections of the strips were very quickly published as books. ${ }^{6}$ The comic was very accessible and recognizable to young readers, who were occasionally even involved in its creative process: when Hergé took a holiday his readers were invited to draw

\footnotetext{
${ }^{5}$ This is the same newspaper the Belgian-American scholar Paul de Man wrote for during his much discussed period as a wartime journalist.

${ }^{6}$ The first being Quick et Flupke gamins de Bruxelles (1931), which was republished as a facsimile edition in 2011 (Editions Casterman).
} 
their own episodes and send them in to be published in Le Petit Vingtième. Besides the main characters, Quick and Flupke, a third character, local policeman number 15, was a crucial part of the gags. Along with other figures - including the mother, the teacher and the upstairs or downstairs neighbours who are often disturbed by the noisy and naughty presence of the boys - he represented adult authority.

The adventures of Quick and Flupke take place largely on the streets of Brussels. This space is defined by fallow land, yards, parks and public gardens. Fences play an important role in many of the gags, since they are useful to peek through or to hide behind. Besides the street, many gags take place indoors in Quick's or Flupke's homes. Other scenarios are the backyard, the school, and the countryside where the boys go on foot to pick fruit, to camp or to ice-skate, and which appears in the strip as within walking distance from the Marolles, a lower class quarter of Brussels. A few gags take place at the seaside (Ostend) and some occur in completely different and exotic settings, such as Switzerland, Scotland or Greenland. These exotic locations are in keeping with an important humoristic technique used in the comic strip: exaggeration. For example, Flupke accidentally ends up in the African desert because he wants to prove to Quick that he can dig a tunnel under the North Sea.

Many of the gags are inspired by French and American slapstick movies. As Zanettin (2008:11) points out, "cinema has been for comics an endless source of plots, characters, faces and techniques". According to Van Opstal (1994), the source of inspiration for Quick \& Flupke was the French movie Les deux gosses, which was released in Belgium in 1929. In this movie two street boys from Paris, Claudinet and Fanfan, live all kinds of amusing adventures on the streets of Paris. Recognizable techniques are borrowed from the slapstick genre. These include: escalation (Flupke tries to hang a painting on the wall. He begins by hammering a nail into the wall but ends up ruining the entire wall, his own finger and the hammer); exaggeration (when Flupke has a toothache we see him cutting down a huge tree and chopping it into pieces until finally he ends up with a small toothpick to relieve his pain); and mistake (when Flupke chases a butterfly with his cap, he mistakenly catches the bow on a woman's hat). The slapstick humour produces a never-ending series of bumps, bruises, broken limbs and bandaged heads caused by explosions, collapses, falling objects, collisions and fights. On many occasions, the characters are drawn 'seeing stars' around their heads and they sometimes end up in hospital.

Although in one sense these gags are timeless, the settings often indicate the interwar period, for example, in the clothes people wear, the style of appliances like radios and vacuum cleaners, and in their visit to a 'Motor Car' Show, where Quick and Flupke see a Bodge (Dodge), a Minerva, and a Duick 
(Buick). The boys sometimes smoke or get drunk, which also suggests norms of a different era for children's behaviour. In the original versions, given their publication in a daily newspaper, there were also quite a few comments on current events. For example, there is a gag about a snowball fight which is called 'Boule de neige ou Sarajevo 1935' (Snowball or Sarajevo 1935). This gag uses the technique of escalation to comment on the riots in Yugoslavia that same year. In another example, in a strip entitled 'Les dictateurs' (The Dictators), Quick, dressed up like Mussolini, and Flupke, dressed up like Hitler, play a game of OXO (the X being replaced by swastikas; Figure 1). These depictions are clearly intended as a mockery of both dictators.

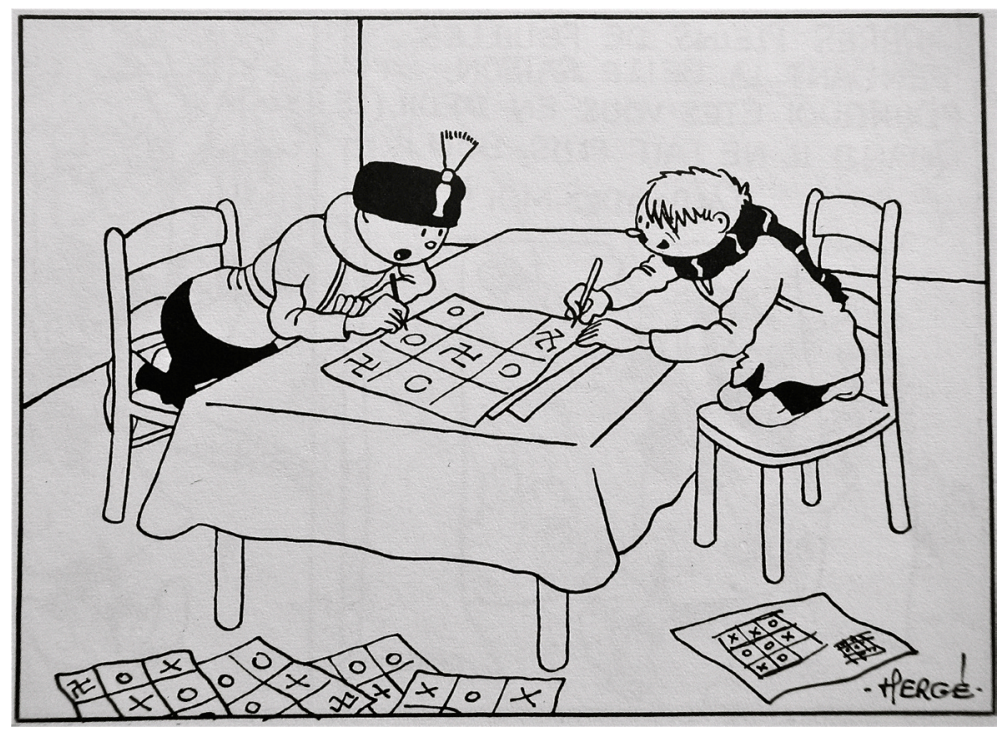

Figure 1. Les dictateurs: a game of OXO by Hitler and Mussolini

Most instances of commentary on the current affairs of that period do not appear in the more recent Casterman editions of Quick \& Flupke, ${ }^{7}$ though some are retained - for example, the strip where Quick has a nightmare and sees a bird with Flupke's head who has come to inform him that Japan has withdrawn from Manchuria, a matter that was high on the political agenda in 1932-1933.

Apart from the speech balloons, textual material is also present in inscriptions on boards and posters on columns, walls and fences which represent actual street scenes in Brussels (Figure 2).

\footnotetext{
${ }^{7}$ The twelve albums published between 1985 and1991 (see list of references in the bibliography).
} 
Inscriptions can also be found on the books and newspapers that the characters read. Sometimes, these are internal references to Hergé: Tintin or Quick \& Flupke, or Le Petit Vingtième. These point to a particular characteristic of this comic strip: in some cases, the fictional illusion is broken and Hergé draws himself playing a part, often to be reprimanded by Quick and Flupke for leading them into awkward situations.

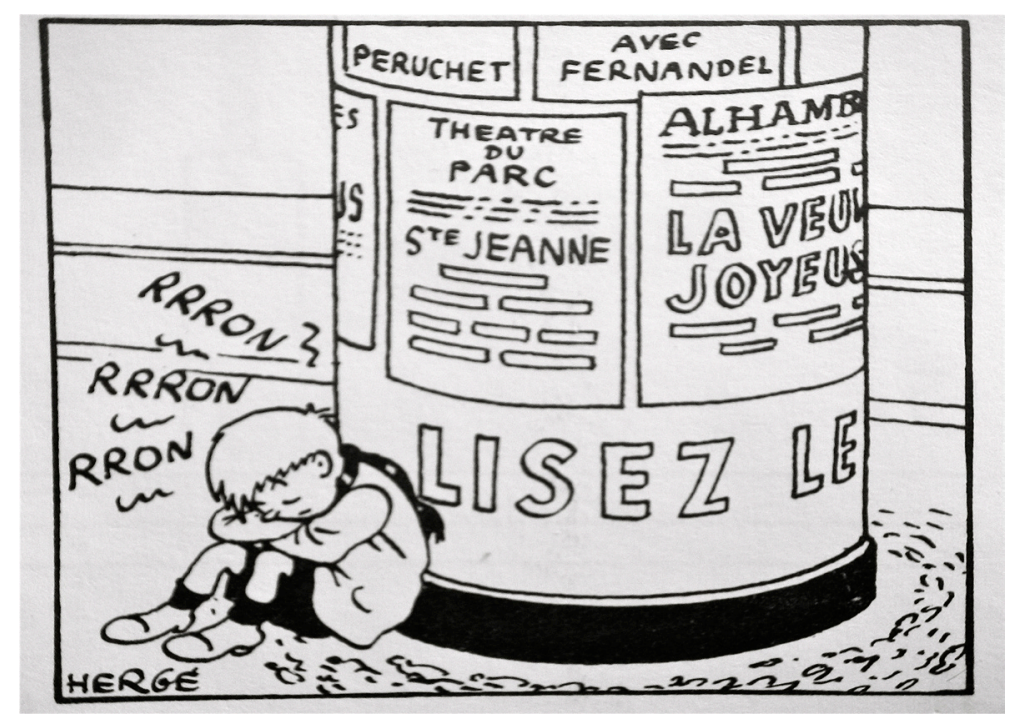

Figure 2. Inscriptions depicting the streets of Brussels

\section{Quick \& Flupke and Hergé: A Brussels question}

Although many authors have tried to prove Tintin's connection to Brussels, tracing every possible relationship between the young reporter and the city, they have ultimately had to acknowledge that Tintin is far less a product of Brussels than Quick \& Flupke. Hergé expert Godin (2007:72; my translation) writes that "more so than Tintin, this comic strip expresses Hergé's love for his Brussels roots"; Hennebert also comments on Hergé's strong connection to Brussels:"We know Hergé was a true Brusseler. His youth in Etterbeek and the Brussels idiom of his immediate surroundings have left their mark even more firmly on Quick and Flupke's adventures than they do on Tintin's" (2004: 8; my translation). ${ }^{9}$

\footnotetext{
8 "Meer nog dan Kuifje geeft deze strip uitdrukking aan Hergés liefde voor zijn Brusselse wortels".

9 "We weten dat Hergé een echte Brusselaar was. Zijn jeugd in Etterbeek en het Brusselse patois van zijn onmiddellijke omgeving drukken hun stempel nog steviger op de avonturen van Kwik en Flupke dan op die van Kuifje".
} 
Georges Remi did indeed grow up in the Brussels community of Etterbeek. His father was francophone, his mother was Dutch-speaking. Hergé used to say he felt more like a Brusseler than a Belgian:"Brussels has influenced me more directly. My mother originated from Brussels. And her mother did not just come from Brussels, she came from the Marolles district. She only spoke Marolles-Flemish, and I think that has influenced me considerably" (Peeters 1983:28; my translation). ${ }^{10}$ Remi was bilingual; Van Opstal describes his linguistic competences as follows (1994:111):

he was a perfectly bilingual belgian but later in life he spoke french and walloon .... in all his schools he was taught in french as well as in dutch; he spoke high flemish there, but with his friends he also spoke low flemish ... until 1932, he heard his mother and his grandmother speak marolles-flemish at home everyday, a low flemish brussels dialect ... the brussels mixed language and the repetitions in two languages were normal for hergé. ${ }^{11}$

During the interwar period, code-switching between Dutch and French was a common practice amongst the indigenous inhabitants of Brussels, especially those who lived in the Marolles (Treffers-Daller 1992:146). Significantly, code-switching did not occur between speakers of the standard variants, but between speakers of the local variants of French and Dutch, who were defined both by their geographic and class location. The comic strip Quick \& Flupke reflected this linguistic and social environment both in the codeswitching that occurs and in the fact that the boys' adventures were mostly situated in the Marolles.

\section{Quick \& Flupke in translation}

In the 1930s and 1940s, many Dutch-speaking Belgians read newspapers in French since many had been educated in French. Hence many people who spoke Dutch (or a variant of Dutch) at home first became acquainted with Quick \& Flupke in French. However, as Reine Meylaerts writes, "in

\footnotetext{
10 "Brussel heeft een directere invloed op me gehad. Mijn moeder kwam oorspronkelijk uit Brussel. En haar moeder kwam niet alleen uit Brussel, maar ook nog uit de Marollenwijk. Ze sprak alleen Marollenvlaams en dat is, geloof ik, iets dat me sterk beïnvloed heeft".

${ }^{11}$ This quote is taken from Van Opstal's Essay $R G$ (1994), which was written entirely without capitals: "hij was een volmaakt tweetalige belg maar sprak zijn latere leven frans en waals. ... thuis sprak hij op last van zijn vader waals. op al zijn scholen kreeg hij les in zowel frans als nederlands; hij sprak er hoogvlaams maar praatte met vrienden ook platvlaams ... tot 1932 hoorde hij thuis dagelijks zijn grootmoeder en moeder konverseren in het marollenvlaams, een platvlaams brussels dialekt. ... de brusselse mengtaal en herhalingen in twee talen vond hij heel gewoon".
} 
the Belgian geopolitical framework the interwar period was a time of many translation-related contacts between the Dutch-speaking and francophone cultures" (2004:293-94; my translation). ${ }^{12}$ The bulk of intra-Belgian translations were from French into Dutch since French was by far the more prestigious language and culture. Indeed, Willemyns has suggested that "until far into the twentieth century 'being Flemish' (and speaking Dutch) in Brussels was associated with poverty and social and cultural deprivation" (2003:343; my translation). ${ }^{13}$

It was during the second World War that the first Dutch translation of a selection of the Quick \& Flupke strip appeared in the Flemish newspaper Het Algemeen Nieuws. ${ }^{14}$ Immediately after the second World War, another strip appeared in the newspaper Ons Volk, more particularly in the supplement Ons Volkske. Although the comic strip genre had become very popular in those postwar years, Dutch-speaking Belgians did not yet have a sufficient number of comics produced in Dutch to meet popular demand. As Zanettin (2008:3) has noted, during the 1930s and 1940s "translated American comics constituted the lion's share of comics published in European ... countries". ${ }^{15}$ Dutch-speaking Belgians thus took to translating francophone Belgian comics like Quick \& Flupke.

Hergé was very much in favour of translating Quick \& Flupke into Dutch. According to Van Opstal (1994: 82), he hired new assistants for the production of his 'Flemish' versions in November 1940, using these versions as an opportunity to redraw the comic, but the work was not completed due to lack of time. Unfortunately, I have not been able to retrieve the names of the translators of the Flemish versions, neither in Het Algemeen Nieuws, nor in Ons Volkske. ${ }^{16}$ These oldest translations do not use standard Dutch as at that time the Dutch language in Belgium was mostly used in dialectical variants. In fact, the original French version did not use standard French either, but rather a local (Brussels) variant.

For the purposes of this article, I have compared the oldest translations

12 "l'entre-deux-guerres est une période de contacts traductionnels priviligiés entre les cultures néerlandophones et francophones à l'intérieur du cadre géopolitique belge".

13 “Tot ver in de twintigste eeuw werd 'Vlaams zijn' (en dus ook Nederlands spreken) in Brussel geassocieerd met armoede en sociale en culturele achterstand".

${ }^{14}$ The first one was published on 23 October 1940.

${ }^{15}$ Eventually well-known Dutch-speaking Belgian comic strip authors like WillyVandersteen and Marc Sleen (who was in charge of Ons Volkske) saw a rise in the sales of their own original productions. This was also possible because of the diminishing stream of American comics to which "many European countries reacted ... with a surge in the publication of works by national authors" (Zanettin 2008:3).

${ }^{16}$ In Het Algemeen Nieuws the translator may have been Eugeen van den Broeck, who was responsible for the newspaper's women's corner and also made the drawings for the children's corner. Another possible candidate is Remi Saen, who was in charge of the children's corner. 
of this strip with the more recent translations dating back to the period 19851991, which are available on the market today. There are currently twelve albums of Quick \& Flupke still available in French and in Dutch, published by Casterman. ${ }^{17}$ The Dutch versions are all translated by the Dutchman René Van de Weijer. In the French versions the 'adaptations' of both text and image have been done by the 'Studios Hergé'. There are also many intermediate publications (French and Dutch) of the comic strips. The most important ones are probably those that appeared in the journals Tintin and Kuifje (from 1946 onwards) and in the albums Les exploits de Quick et Flupke/De guitenstreken van Kwik en Flupke, which appeared between 1949 and 1961 and were reprinted several times. The translation of the strips into Dutch in these albums was probably undertaken by Tintin translator François van der Drift. In 2011, Casterman reprinted these albums in two volumes (a French and a Dutch version, based on translations dating from 1975, which are probably a revision of Van der Drift's work by Van de Weijer). ${ }^{18}$

In the next section I indicate some of the changes in the translations I found when comparing four versions of the strips. ${ }^{19}$ The first version is the original French version (OF), first published in Le Petit Vingtième. The translations are taken from the second part of the series Archives Hergé (1978) in which 119 of the original strips are reproduced. For the second version (OD), I took those 119 strips as a starting point. I searched the oldest Dutch translations in the newspapers Ons Volk and Het Algemeen Nieuws for overlaps with these 119 and found 50 'matches' to use in my analysis. Finally, I examined the twelve Casterman albums currently on the market for the third and fourth versions of these strips, which I refer to as MF (modern French) and MD (modern Dutch). In the following selection of just a few examples out of many, I focus on three discursive aspects of the originals and the translations: loans, use of bilingualism and cultural references.

\subsection{French loan words in Dutch}

The oldest Dutch translations retain many French words, a common practice in Flemish (dialects) at the time. French words like merci (thank you), voila

\footnotetext{
${ }^{17}$ The titles are (French/Dutch): Jeux interdits/Verboden spelletjes, Tout va bien/Niks aan de hand, Toutes voiles dehors/Alle zeilen bij, Chacun son tour/Ieder op zijn beurt, Pas de quartier/Erop of eronder, Pardon madame/Pardon mevrouw, Vive le progrès/Leve de vooruitgang, Catastrophe/Wat een ramp, Farces et attrapes/Vuurwerk, Coups de bluff/Pure bluf, Attachez vos ceintures/Riemen vast. The twelfth one, Haute tension/Hoogspanning, was written and drawn by Johan De Moor, son of Hergé's colleague Bob De Moor.

${ }^{18}$ For more information on the complex publication history of Quick \& Flupke, see www. zilverendolfijn.nl (last accessed 2 January 2013) and Van Opstal (1994:129). See also http://www.duizend-bommen.eu (last accessed 2 January 2013).

${ }^{19}$ A comparison of these versions with the intermediate versions would make an interesting topic for further research.
} 
(there you are) and madame are kept in the OD. In the modern Dutch version, MD, however, they are replaced by the standard Dutch words dank je, ziezo and mevrouw, respectively. The same happens with proper names: for example, the French name Jules is kept in the OD but replaced by the very Dutch name Joris in the MD. ${ }^{20}$ In one example where an (imaginary) butler, Firmin, appears, the OD retains the French name, but in the MD version the name is changed to the English James ${ }^{21}$ pointing to the increasing dominance of Anglo-Saxon culture after World War II, which made the name James recognizable as a more 'typical' name for a butler.

\subsection{Dutch loan words in French}

The oldest French version (OF) sometimes uses Dutch loans. In the strip entitled 'Grand nettoyage'22 (The big clean), Quick accidentally sprays water on two neighbours with a hose. The woman calls out from her window: "Attendeie que je descends seulement une minute, tu vas voir quelle "rammeling" tu vas recevoir" (Wait a minute till I come down, you will see the thrashing you will receive). In the modern French version, the Dutch word rammeling (thrashing) is replaced by the French corrections ("Si je descends, tu vas recevoir une de ces corrections!!...”). The woman depicted no longer speaks Brussels French; she now speaks standard French, in other words, she is no longer bilingual, but has become monolingual.

A similar example can be found in the strip entitled 'Quick fait de l'auto' (Quick behind the wheel), ${ }^{23}$ in which a woman gets run over by a car driven by Quick. In her outrage, in the OF she uses the Dutch colloquial swear word Potferdeke (Darn; Figure 3a). While the OD retains this swear word (Figure $3 \mathrm{~b}$ ), the MF gets rid of the loan word and uses the French standard exclamation Bon dieu (Dear God), which is no longer considered a swear word (Figure 3c), and the new Dutch version (MD; Figure 3d) uses the standard and inoffensive Lieve hemel (Good heavens).

\footnotetext{
${ }^{20}$ Le monde tel que le voudrait Flupke, Archives 152-153, Le monde tel que le voudrait Flupke, Catastrophe, 12-13, De modelleerling, Ons Volkske, 15(29), 26 July 1951, 475, De wereld volgens Flupke, Wat een ramp, 12-13.

${ }^{21}$ Si j'avais un million, Archives 190-191, Si j'avais un million, Pardon Madame, 2-3, (No title), Ons Volkske 15(1), 4 January 1951, 11, Als ik een miljoen had, Pardon Mevrouw, 2-3.

${ }_{22}$ Grand nettoyage, Archives 24-25, Grand nettoyage, Attachez vos ceintures, 2-3, Kwik is zeer bedrijvig, Het Algemeen Nieuws 1 July 1943, Grote schoonmaak, Riemen vast, 2-3.

${ }^{23}$ Quick fait de l'auto, Archives 34-35, Quick fait de l'auto, Tout va bien, 34-35, De al te gedienstige Kwik, Het Algemeen Nieuws 8 July 1943, Quick in de bocht Niks aan de hand, 34-35.
} 

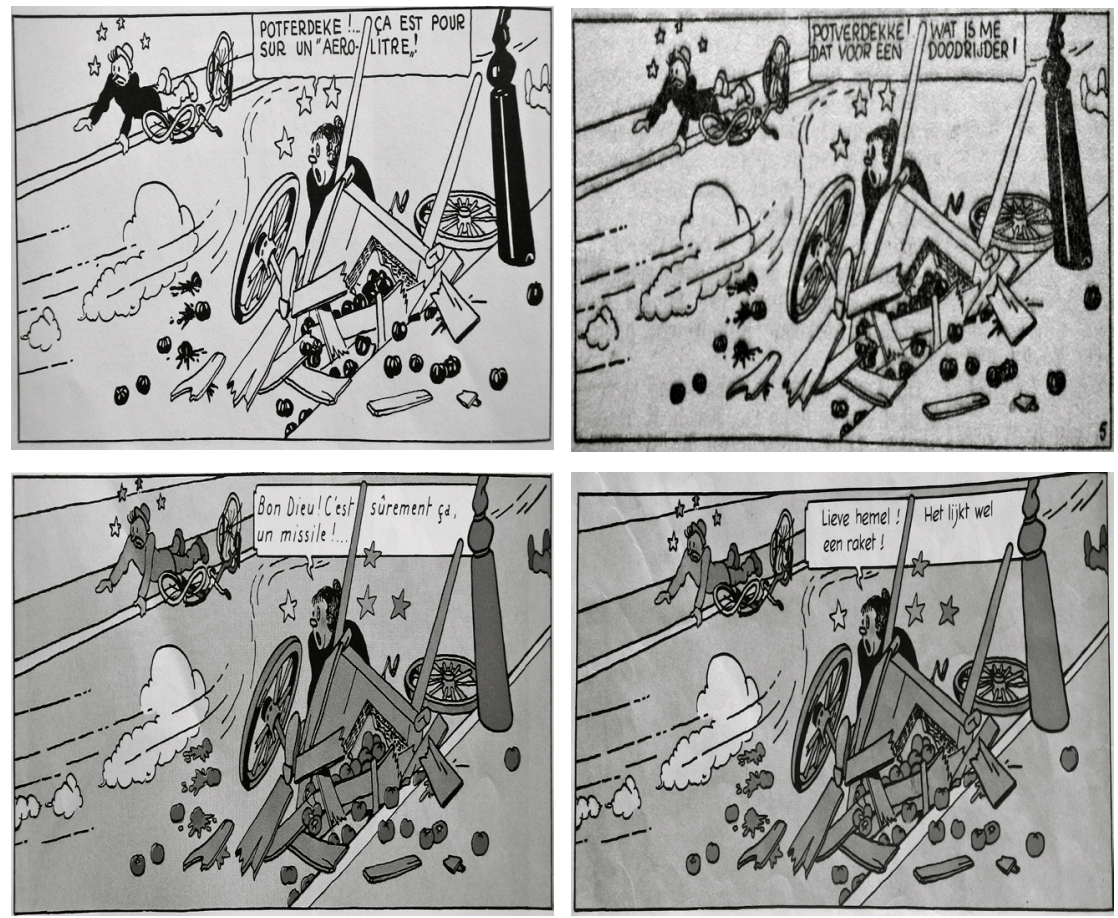

Figure 3. Quick fait de' 'l auto. The street vendor uses four different swear words

Another interesting example is the word fiske, used in the OF and in the OD in a number of the gags. The word is composed of the stem fils (French for 'son') and the suffix ke (a Dutch - Flemish variant - diminutive). This mixed word is not retained in the MF or MD versions, but is replaced by a non-mixed variant (fiston) or simply dropped.

\subsection{Loans, puns and bilingualism}

Textual material on posters, signposts and other objects is not always translated. Often it is just eliminated. Especially in the most recent versions, there are quite a few empty posters on the fences and columns and books without writing on the covers. When they are translated, however, they can be very revealing. In the OF episode 'Quick apprend la boxe' (Quick learns to box), Quick and a friend stand in front of a poster announcing a boxing match between Sam Suffy and Mac Aronni. ${ }^{24}$ Sam Suffy is a pun on 'ça me suffit', which

\footnotetext{
${ }^{24}$ Quick apprend la boxe, Archives 30-31, Quick apprend la boxe, Attachez vos ceintures, 8-9, Quick krijgt boksles, Riemen vast, 8-9, Kwik, bokser, Het Algemeen Nieuws, 22 July 1943.
} 
means 'I've had enough'. This pun is retained in the OD version as the readers would have no difficulties understanding it. In the MD version, however, the name is changed into Mac Suffy, which erases both the pun and the assumed bilingualism of Brussels and the street scene depicted. A new pun in Dutch replaces the old French one: Mac Suffy means Lame Idiot (Mak Suffie).

In the strip where Quick learns to drive a car there is a bilingual signpost announcing a road block: Rue barrée/Afgesloten straat (Figure 4a). ${ }^{25}$ The OD still has the two languages on the signpost (Figure 4b). The MF as well as the MD, however, both show a monolingual signpost (Figures $4 \mathrm{c}$ and 4d). Again, the bilingual street scene of Brussels is replaced by two monolingual street scenes, one in French and one in Dutch. This also blocks the identification of the comic strip with Brussels and situates it within a more anonymous or universal setting.
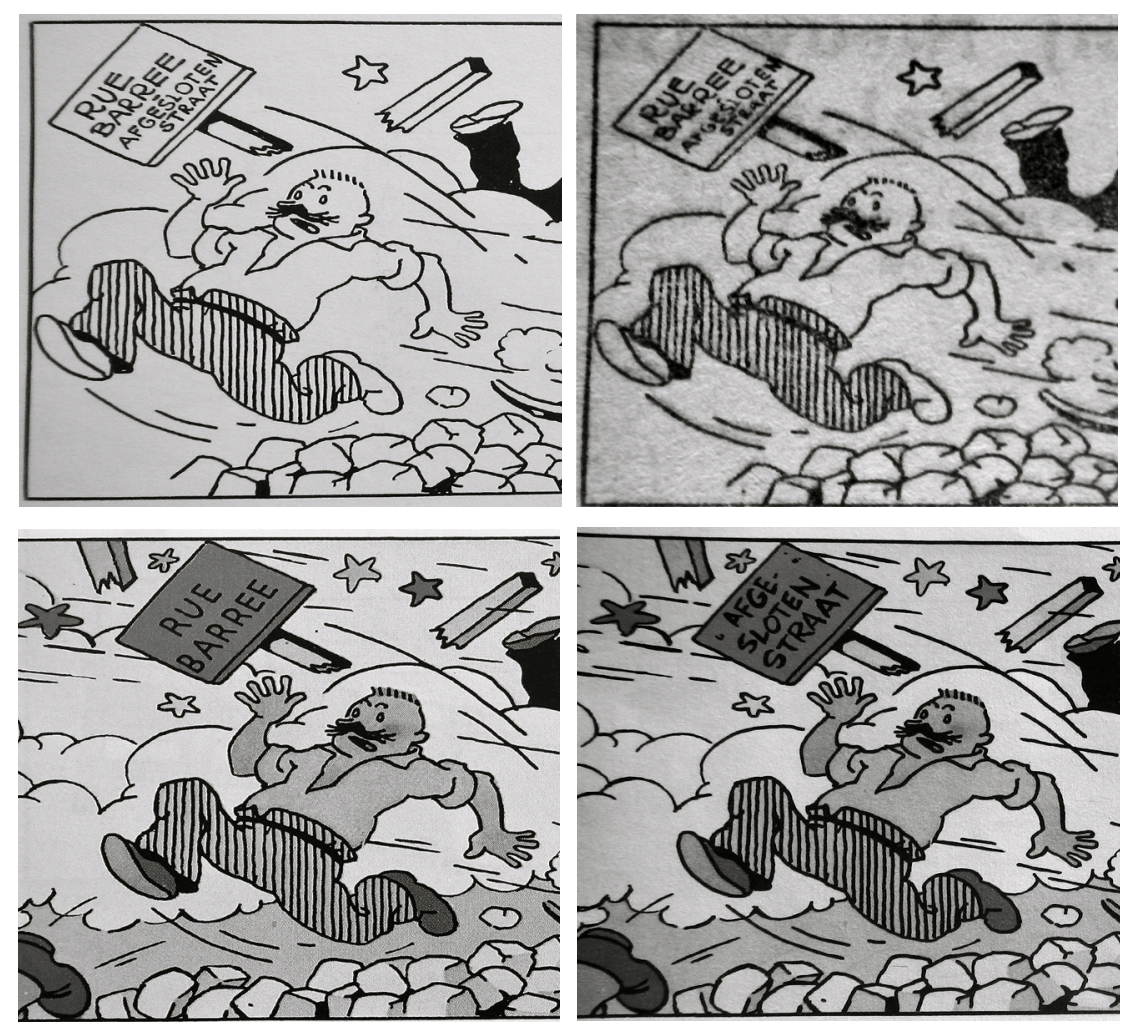

Figure 4. Quick fait de l'auto. Road sign indicates the shift to monolingualism

\footnotetext{
${ }^{25}$ Si j'avais un million, Archives 190-191, Si j'avais un million, Pardon Madame, 2-3, (No title), Ons Volkske 15(1), 4 January 1951, 11, Als ik een miljoen had, Pardon Mevrouw, 2-3.
} 


\subsection{Cultural references}

In the OF episode 'Saint-Nicolas', Flupke gets up on the morning of 6 December and immediately realizes it is the special day of Saint Nicolas, the children's saint who brings toys on that day. ${ }^{26}$ The festivities that take place on Saint Nicolas' birthday are part of a longstanding tradition in Belgium and the Netherlands. However, the modern French version of the strip replaces this local saint with Father Christmas and the date with 25 December. Here we have a clear example of how the MF replaces Belgian culture with French culture. The MD however retains the reference to Saint Nicolas because he is very well known and loved throughout the Netherlands.

In the OF strip, 'Un peu d'histoire' (A little history), Quick and Flupke watch a historical parade and decide to re-enact one of the episodes themselves. ${ }^{27}$ Flupke dresses up as a Roman and Quick as a Nervian, a member of a Belgian tribe from Roman times, both famous for Julius Caesar's praise of their bravery. Two panels later the battle has begun and both boys engage in a battle cry that transports them from the Roman era. Quick (the former Roman) calls out: "Schild en vriend" (Shield and friend). According to legend, this call was used by the Flemish during the Battle of the Golden Spurs (1302), in order to identify them as Flemish against their French enemies who could not pronounce the phrase. Flupke (the former Nervian) calls out "ralliez-vous à mon panache blanc" (gather around my white feather), a phrase used by the French king Henri IV when he led his troops to victory in the Battle of Ivry (1590) during the French religious wars. When discussing the battle, both boys mention the soldier of Marathon and 'the Thermopyles'. Quick also mentions that the Romans were slaughtered by a weapon known as de goedendags, again a reference to the Battle of the Golden Spurs. The entire cartoon is a comedic mixture of historic references. The old Dutch (OD) translation replaces this mix by using only the setting of the Battle of the Golden Spurs. This battle against the French is one of the most important legends through which the Flemish have constructed their identity and their case for autonomy.

In the modern French version, the Romans are retained but the Nervians are replaced by the Gauls, so the Germanic tribe is replaced by the forefathers of the French. In this version, Quick invokes the war cry 'J'y suis, j'y

\footnotetext{
${ }^{26}$ Saint-Nicolas, Archives, 72-73, Joyeux Noël, Tout va bien, 6-7, Flupke's Sint-Niklaas, Het Algemeen Nieuws 10 December 1942, Sinterklaas, Niks aan de hand, 6-7.

${ }^{27}$ The oldest French version of this episode I found is in the facsimile edition of Les exploits de Quick \& Flupke: Un peu d'histoire, Les exploits de Quick \& Flupke $1^{e}$ volume, 44-45, Un peu d'histoire, Pas de Quartier, 2-3, Kwiks Guldensporenslag, Het Algemeen Nieuws 12 June 1941, Een brokje geschiedenis, Erop of eronder, 2-3.
} 
reste" (Here I am, here I stay), first used by the French commander during the Crimean War in 1855; Flupke's cry about the feather, however, is retained. The Flemish legendary weapon, the so-called Goedendag, is replaced by the Turkish sword yatagan though the references to the Greek battles remain. Thus in the MF, although the mixture of historical battles and facts is still present, all the elements referring to Belgian history are replaced mostly by terms referring to French history.

Finally, the modern Dutch version also references the Romans, but introduces another tribe: the Batavians, a Germanic tribe linked to the origins and identity of the Netherlands. The historical battle cries are replaced by the non-specific 'Come on' and 'Follow me' and the references to the Greek battles are dropped. The soldier of Marathon is replaced by the Unknown Soldier. Hence, the historical mix present in the other versions disappears.

These four versions reveal significant differences: each version uses the historical facts and figures that suit the target culture for which the comic strip is intended. The OF, aimed at both French- and Dutch-speaking Belgian readers, is the most hybrid and the only one that uses Dutch loans words in the French text (schild en vriend, goedendag). The OD, aimed at a Dutch-speaking Belgian readership, uses the episode to teach young readers a (biased) history lesson. The others replace all Belgian and Flemish specificity by French (MF), Dutch (MD) and 'general' references (both versions). The MF addresses a francophone audience, from both Belgium and France, whereas the MD addresses a Dutch-speaking audience, from both Belgium and the Netherlands.

Finally, Zanettin (2008:21) has pointed out that when comics are republished, for example, OF to MF, or translated, "[v]erbal language is not the only component ... which gets translated, since visual components are often modified as well". The Quick \& Flupke comic strip has been redrawn, (re)coloured and relettered several times by Hergé and his Studio. Although an analysis of these visual changes lies beyond the scope of this article, one type of change supports my findings on the neutralizing shifts that take place at the textual level. This example concerns the depiction of a common scene typical of the Marolles quarter (OF), which is replaced by a more neutral, less socially-marked middle class scene (MF) specifically with regard to the appearance of Madame Sylvie in the episode 'Simple emprunt' (To borrow something) (Figures 5a and 5b). ${ }^{28}$

\footnotetext{
${ }^{28}$ Simple emprunt, Archives, 56-57; Simple emprunt, Farces et attrapes, 18-19.
} 

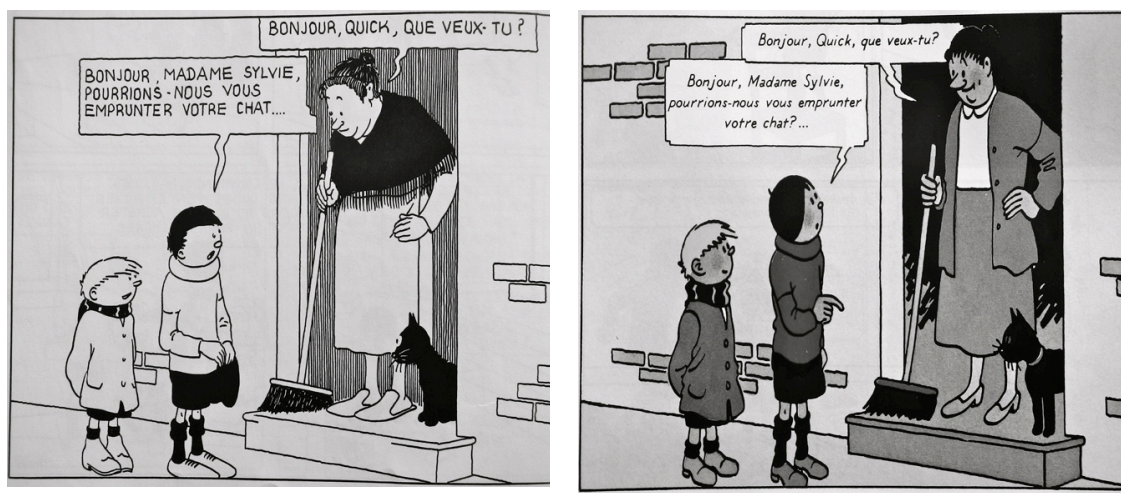

Figure 5. Simple Emprunt. Madame Sylvie climbs the social ladder

\section{Loss in translation?}

The main tendency in the above examples seems to be towards standardization. The shift towards monolingualism is one aspect of this standardization process. Over the course of the 20th century Belgium evolved politically from a unitarian state towards a federalized one with two monolingual regions, Flanders and Wallonia, and a bilingual capital, Brussels (Meylaerts 2007:316). In her examination of the social factors explaining the disappearance of French-Dutch code-switching in Brussels, Treffers-Daller (1992:145) points out that

since the 1960s, the socio-political climate in Brussels has been severely affected by the ongoing conflict between the Dutch-speaking and the French-speaking population groups concerning the federalization of the state, in which the struggle over the status of Brussels was one of the most difficult issues .... In such a situation the Brusselers may no longer consider a mixed code to be an appropriate expression of their identity.

She concludes that "the tension between the linguistic groups in Belgium has probably created an unfavourable climate for codeswitching. ... bilingualism is not considered to be emblematic of the local identity" (ibid.:155).

In the 1990s, when the most recent Dutch translations of Quick \& Flupke were published, bilingualism was thus no longer crucial to the image Belgians or Brusselers had of their social environment. A bilingual Brussels was no longer the 'imagined community' of the people who believed themselves to be part of that group. Aneta Pavlenko (2004:17) argues that

[i]magination plays a crucial role in the process of creation of new identity options or ... in the process of imaginative production of identity. This process is often aided by new terms, by visual art, and by literary narratives, which together create new practices of self- representation and thus new 'imagined communities. 
She goes on to explain that "narratives play a particularly important role in our account of negotiation of identities" (ibid.:18). When Quick \& Flupke was originally conceived and first translated in the 1930s and 1940s, it represented a narrative of words and images of Brussels' bilingual identity, both in the original and in the early translations. However, the translated versions currently available no longer represent that same cultural identity: they represent two separate identities: one Dutch and one French. The 'interculture' between the two appears to have lost its significance (Meylaerts 2004).

This tendency towards monolingualism is consistent with a more encompassing trend towards language standardization and away from the use of dialects. The terms 'standard' and 'dialect', according to Federici, represent, respectively, the "prestige variety of language used within a speech community" (2011:6) and a "regionally or socially distinctive variety of language, identified by a particular set of words and grammatical structures" (ibid.:9).

In the OF version of Quick \& Flupke there are clear references to Brussels French.This dialect has two interesting components: it is both socially and geographically defined and clearly situates the comic strip within the lower classes of Brussels, and in the Marolles quarter. The dialect is supported visually by the common scenery of this quarter. This socially, linguistically and geographically identifiable landscape, however, is standardized and neutralized in the intralingual translations (OF to MF and OD to MD) as well as in the interlingual ones, both in the written language and the illustrations.

It is worth noting that France is a large market for these cartoons. The publisher, Casterman, is part of the French group Flammarion, which is in turn part of the Italian RSC Media Group. The publishing conditions are therefore very different from those of the OF and OD publications in Belgian newspapers. By the time the Casterman MF and MD albums were published, Hergé had become world famous; and in the wake of Tintin's success Casterman aimed for an international readership for Quick \& Flupke. ${ }^{29}$ This might explain why the original Brussels French evolved towards the standard French norm. The same developments can be seen in the interlingual translations. The first translations made use of a dialectical Flemish variant of Dutch. The most recent translations, however, are in standard Dutch, as spoken in the Netherlands. ${ }^{30}$

\footnotetext{
${ }^{29}$ In 1992 Jeux interdits and Tout va bien were translated into English by Tintin-translators Leslie Lonsdale-Cooper and Michael Turner. In 2008 eleven English albums were published in India by Eurobooks (http://www.eurobooksindia.com, last accessed 2 January 2013). Several unofficial sources on the internet mention that two of those were released in the UK. Those two, translations of Toutes voiles dehors and Attachez vos ceintures, were apparently retranslated for the UK market.

See http://www.swapmeetdave.com/Humor/Quick-Flupke/index.htm (last accessed 2 January 2013) and the entry on Quick \& Flupke in Wikipedia.

${ }^{30}$ The most recent Dutch version is not only based on the most recent French version, but has probably taken into account older French versions as well. For example, some inscriptions that are left out in the MF are retained in the MD.
} 
Whereas in Belgium about 6 million people speak Dutch, in the Netherlands there are 16 million. In addition to the obvious economic reasons for the changes made in the translations, there are also cultural-political reasons, as Pavlenko and Blackledge suggest: "in multilingual settings, language choice and attitudes are inseparable from political arrangements, relations of power, language ideologies, and interlocutors' views of their own and others' identities" (2004: 1). As Meylaerts (2008b:29) has noted, Belgium and Brussels are home to two minority languages, French and Dutch, with both 'Belgian' languages situating themselves on the periphery of larger neighbouring nations - the Netherlands and France - both of whom dominate Belgium linguistically, economically and culturally. This becomes very clear in both the intralingual and the interlingual translations of Quick \& Flupke, where cultural references to Brussels or Belgium are replaced by references to France, the Netherlands, or to a more general globalized context.

As for the interlingual translations from French into Dutch, it needs to be stressed that after World War II there was an increasingly strong insistence on adopting Dutch norms prevalent in the Netherlands for Dutch-speaking Belgians, ${ }^{31}$ as the view grew that the Flemish people needed a strong standard language to resist the dominance of French, especially as their own regional variants of Flemish and all its dialects were thought to be socially and culturally inferior. This insistence on standard Dutch - as opposed to Flemish variants - was a very important factor in the resistance of Dutch-speaking Brusselers to code-switching. In the view of Treffers-Daller (1992:154), the disappearance of code-switching in Brussels among Dutch-speaking inhabitants can indeed be partly "attributed to the puristic influence of standard Dutch". This explains why the first translations did not hesitate to use loans and bilingual inscriptions, yet later translations considered these to be shortcomings and replaced them by 'pure' and standard Dutch. The appeal of the romantic ideology of 'one language and one literature for one nation' by the so-called Flemish Movement - which had striven for more rights for Flanders since the 19th century and had been quite successful after WWII - suggested that any form of literary code-mixing must be deemed undesirable.

\section{Concluding remarks}

Zanettin (2008:8) has suggested that "[w] of genre, readership, publication format (or a combination of the three) may be involved which will then govern primary translation choices". In the case of Quick \& Flupke, although the genre remained the same, the readership and the publication format did not. The change in publication format from newspaper

\footnotetext{
${ }^{31}$ It is the case, however, that since the 1990s, when the last translations of Quick \& Flupke were undertaken, this situation has changed for Dutch. Increasingly, a Flemish linguistic norm separate from the Dutch norm of the Netherlands has gained acceptance.
} 
comic strip to comic book was closely linked to a change in intended readership, and in this case, the various target communities to which the comic strip was directed did indeed "govern primary translation choices".

I discussed translation strategies on the micro-level to show how these strategies were linked to the relation between the cultural identities of Brussels, Belgium, francophone Belgium and Flanders. Between the 1930s and the 1990s, translation strategies that involved erasing bilingualism and code-switching, removing cultural references to Belgium and neutralizing and standardizing both text and image reflected the increasing estrangement between the language communities, not just passively mirroring the widening gap, but also actively helping to create it.

My analysis has also shown the importance of economic factors in determining translation strategies and choices, even on the micro level. In its modern French and Dutch versions, Quick \& Flupke was better suited to an international market. To ensure this, the local context had to be translated out of the comic strip. A less local version also made it easier for the albums to be translated into a range of other languages, including English and German, and cultural references were increasingly adapted to 'globalized' stereotypes. For Quick \& Flupke, as for Tintin, the dwindling importance of the Belgian market also became increasingly apparent in such translation choices.

A quick glance at the more recent versions of Tintin, however, offers the promise of a return to the local through translation. In addition to dozens of official languages, Tintin has begun to be translated into an increasing number of local languages and dialects, including 'Brussels'. ${ }^{32}$ There are currently two versions of the albums, one in Dutch and Marols and another in French and Marols. Tintin is thus being translated into dialects that have much more in common with the oldest French and Dutch versions of Quick \& Flupke. Should they follow Hergé's favourite son, these boys may be on their way to being translated back into their old selves.

\section{ELKE BREMS}

Warmoesberg 26, 1000 Brussel, University College Brussels (KU Leuven Asociation),Belgium.Elke.Brems@hubrussel.be

\section{Acknowledgement}

All illustrations are reproduced courtesy of Moulinsart.

\section{References}

\section{Corpus}

Archives Hergé. Tome 2: Quick et Flupke (1978) Tournai: Casterman. Het Algemeen Nieuws 1940-1944.

\footnotetext{
${ }^{32}$ See http://www.tintinaroundtheworld.info/print.php (last accessed 2 January 2012).
} 
Ons Volkske 1945-1955.

Quick \& Flupke (1985) Tournai: Casterman.

------ 'Jeux interdits'.

------ 'Tout va bien'.

'Verboden spelletjes'.

Quick \& Flupke (1986) Tournai: Casterman.

----- 'Alle zeilen bij'.

------ 'Ieder op zijn beurt'.

------ 'Chacun son tour'.

------ 'Toutes voiles dehors'.

------ 'Niks aan de hand'.

Quick \& Flupke (1987) Tournai: Casterman.

----- 'Erop of eronder'.

------ 'Leve de vooruitgang'.

----- 'Pardon madame'.

------ 'Pardon mevrouw'.

------ 'Pas de quartier'.

------ 'Vive le progrès'.

Quick \& Flupke (1988) Tournai: Casterman.

----- 'Catastrophe'.

'Wat een ramp'.

Quick \& Flupke (1989) Tournai: Casterman.

------ 'Farces et attrapes'.

------ 'Vuurwerk'.

Quick \& Flupke (1990) Tournai: Casterman.

------ 'Coups de bluff'.

------ 'Pure bluf'.

Quick \& Flupke (1991) Tournai: Casterman.

----- 'Attachez vos ceintures'.

------ 'Riemen vast'.

\section{Secondary Sources}

De Bens, Els and Karin Raeymaeckers (2007) De pers in België. Het verhaal van de Belgische dagbladpers gisteren, vandaag en morgen, Lannoo: Tielt.

Federici, Federico M. (2011) 'Introduction: Dialects, Idiolects, Sociolects: Translation Problems or Creative Stimuli’, in Federico M. Federici (ed.) Translating Dialects and Languages of Minorities, New Trends in Translation Studies 6, Bern: Peter Lang, 1-20.

Godin, Philippe (2007-2008) De kunst van Hergé. Schepper van Kuifje, Deel I \& II, Brussels: Editions Moulinsart.

Hennebert, Diane (2004) 'Brussel, spookstad', in Geert van Istendael (ed.) Kuifje en de stad, Brussels: Moulinsart, 6-11.

Meylaerts, Reine (2004) 'La traduction dans la culture multilingue. A la recherche des sources, des cibles et des territoires', Target 16(2): 289-317. 
(2007) “'La Belgique vivra-t-elle?” Language and Translation. Ideological Debates in Belgium (1919-1940)', The Translator 13(2): 297-319.

----- (2008a) “"Ils sont comme nous": les revues francophones belges et la Flandre (1919-1939): pour une approche marco- et microsociologique combine', COnTEXTES 4. Available at http://contextes.revues.org/3843? \&id=3843 (last accessed 2 January 2013).

----- (2008b) 'Identité “propre” ou identité “empruntée” des littératures mineures? Hétérolinguisme dans la traduction littéraire intra-belge', Alternative Francophone 1(1): 29-45.

Noppen, Hans (2009) 'Ghij doolt dikwijls in 't spellen van uw Nederduitsch \& Familiezaken', in Duizend bommen 29 \& 30. Available at http://www.duizend bommen.eu (last accessed 2 January 2013).

Pavlenko, Aneta and Adrian Blackledge (2004) 'Introduction: New Theoretical Approaches to the Study of Negotiation of Identities in Multilingual Contexts', in Aneta Pavlenko and Adrian Blackledge (eds) Negotiation of Identities in Multilingual Contexts, Clevedon: Multilingual Matters,1-33.

Peeters, Benoit (1983) De wereld van Hergé, Tournai: Casterman.

Screech, Matthew (2005) Masters of the Ninth Art: Bandes Dessinées and FrancoBelgian Identity, Liverpool: Liverpool University Press.

Soncini Fratta, Anna (ed.) (1994) Tintin, Hergé et la 'Belgité', Bologna: Clueb.

Treffers-Daller, Jeanine (1992) 'French-Dutch Codeswitching in Brussels: Social Factors Explaining Its Disappearance', Journal of Multilingual and Multicultural Development 13(1/2): 143-56.

Van Opstal, H. (1994) Essay RG. Het fenomeen Hergé, Hilversum: Delange.

Van Parijs, Philippe (2011) 'Omdat Brussel ons Jeruzalem is', De Standaard, 14 June. Available at http:/www.uclouvain.be/cps/ucl/doc/etes/documents/2011.06.14. DS.Omdat_Brussel_ons_Jeruzalem_is.pdf (last accessed 2 January 2013).

Zanettin, Federico (2008) 'Comics in Translation: An Overview', in Federico Zanettin (ed.) Comics in Translation, Manchester: St Jerome Publishing, 1-32. 